\author{
ELISABETTA GARGANI $(*)$ - GIUSEPPE MAZZA $(*)$ - CLAUDIA BENVENUTI $(*)$ - GIULIA TORRINI $(*)$ \\ AGOSTINO STRANGI $(*)$ - FABRIZIO PENNACCHIO $\left(^{*}\right)$ - PIO FEDERICO ROVERSI $(*)$
}

\title{
BIOLOGICAL CONTROL OF ACLEES SP. CF. FOVEATUS AND FIRST RECOVERY OF AN ASSOCIATE BEAUVERIA BASSIANA STRAIN
}

\begin{abstract}
(*) Consiglio per la ricerca in agricoltura e l'analisi dell'economia agraria (CREA-ABP) - Research Center for Agrobiology and Pedology, Via Lanciola 12/A, 50125, Florence, Italy; ;-mail: elisabetta.gargani@crea.gov.it

Gargani E., Mazza G., Benvenuti C., Torrini G., Strangi A., Pennacchio F., Roversi P.F. - Biological control of Aclees sp. cf. foveatus and first recovery of an associate Beauveria bassiana strain.

Aclees sp. cf. foveatus (Coleoptera: Curculionidae) is spreading in Central Italy, causing severe infestation on fig trees. There are very few information for this pest and no natural enemy is reported. Here, we report the first recovery of a natural enemy associated with this invasive weevil, a strain of the entomopathogenic fungus Beauveria bassiana. The potential use of entomopathogenic fungi and nematodes as biocontrol agents was tested against adults in laboratory trials. In agree with the detection in nature, only treatments with $B$. bassiana were able to control the insects. This result opens new frontiers for the environmental friendly control strategies against this weevil.
\end{abstract}

KeY WorDS: alien invasive pest, biocontrol, entomopathogenic fungi, fig weevil, natural enemies.

\section{INTRODUCTION}

Few severe enemies are reported for Ficus carica L. (e.g. Pollini, 1998; MAZZA et al., 2014a), but in 2005 the introduction of the invasive Aclees sp.cf. foveatus Voss (Coleoptera: Curculionidae) in Central Italy, in particular in Tuscany, caused serious symptoms of decay on fig trees (CIAMPOLINI et al., 2005; BENELLI et al., 2014).

At now, the systematic of this weevil remains unclear, mainly due to the absence of a recent revision of the entire genus Aclees (Morimoto, 1982) and, as expected, information on biology, and management of this weevil are scanty (CIAMPOLINI et al., 2007, 2008; BENELLI et al., 2014).

Since the situation in Tuscany is already compromised and the species spread in five on ten provinces (Phytosanitary Service of Tuscany, pers. com.), the aim of this paper is to improve the knowledge on the potential biological control against this invasive weevil. In addition, with this aim, we report the finding of the first natural enemy associated to this insect: a strain of the entomopathogenic fungus Beauveria bassiana Balsamo (Vuillemin), directly isolated from a dead adult found in Prato province, an area of recent introduction.

\section{MATERIAL AND METHODS}

INSECT COLLECTION AND LABORATORY MAINTENANCE

Adults with a balanced sex ratio, were collected during field surveys from July to October 2015, in fig orchards located in three sites between Prato and Lucca provinces (Fig. I.1). The specimens were transferred to the facilities of CREA-ABP in Florence (Italy), sexed following the criteria used in THU et al. (2010) and maintained at 26-28 ${ }^{\circ} \mathrm{C}$ with 16:8 (L:D) photoperiod, in cages with chipboard and wood portions of fig, with the addition of apple slices.

ISOLATION AND IDENTIFICATION OF THE FUNGAL STRAIN

The fungal strain was isolated from a dead adult (Fig. I.2) collected during field survey in Carmignano (Prato), Tuscany
(N 43.81.43, E 11.01.94., altitude ca. $186 \mathrm{~m}$ a.s.1.). The adult was stored in sterile $50 \mathrm{~mL}$ tube until fungal isolation. The isolate was subcultured in Petri dishes on Sabouraud Dextrose Agar (SDA) plus $0.25 \%(\mathrm{w} / \mathrm{v})$ yeast extract (SDAY) and maintained in a climatic chamber at $25 \pm 1{ }^{\circ} \mathrm{C}$.

Fungal strain was subcultured and an aliquot of mycelium and conidia (about $10 \mathrm{mg}$ maximum) was collected, frozen at $-140{ }^{\circ} \mathrm{C}$ and pulverized with Precellys 24 (Precellys). Genomic DNA was extracted using the DNeasy Plant Mini Kit (QIAGEN) according to the manufacturer's instructions. Amplification and sequencing of ITS locus and $\beta$-Tubulin was performed according to WHITE et al. (1990) and GLASS \& DONALDSON (1995) using the universal primers ITS1 - ITS4 and $\mathrm{Bt} 2 \mathrm{a}-\mathrm{Bt} 2 \mathrm{~b}$.

PCR product was sequenced at the Centro di Servizi per le Biotecnologie di Interesse Agrario Chimico ed Industriale (CIBIACI), Università degli Studi di Firenze, Italy. The sequence was submitted to GenBank: accession n. KU726564 and KU867831.

Maximum Likelihood (ML) phylogenetic reconstruction method was used to identify fungal strain at species level. The alignment obtained from homologous ITS sequences was used for the subsequent analyses. ML tree was built with MEGA 6.0 (TAMURA et al., 2013) using TN93 as substitution matrix assuming a gamma-distributed substitution rate among sites and performing 2000 bootstrap replicates.

Phylogenetic tree based on Bayesian Inference (BI) was constructed using BEAST v. 2.3.2 (DRUMMOND \& RAMBAUT, 2007 ) assuming the same substitution matrix and the coalescent constant population model. Analyses were run for 10 million generations, sampling every 1000 generations (first $10 \%$ discarded as burn-in). Five independent Markov chain Monte Carlo (MCMC) analyses were performed starting from a randomly chosen tree. Maximum clade credibility tree was summarized.

\section{Pathogenicity assays}

Entomopathogenic nematodes and fungi were selected to perform lab control trials on the adults. Bioassays were 

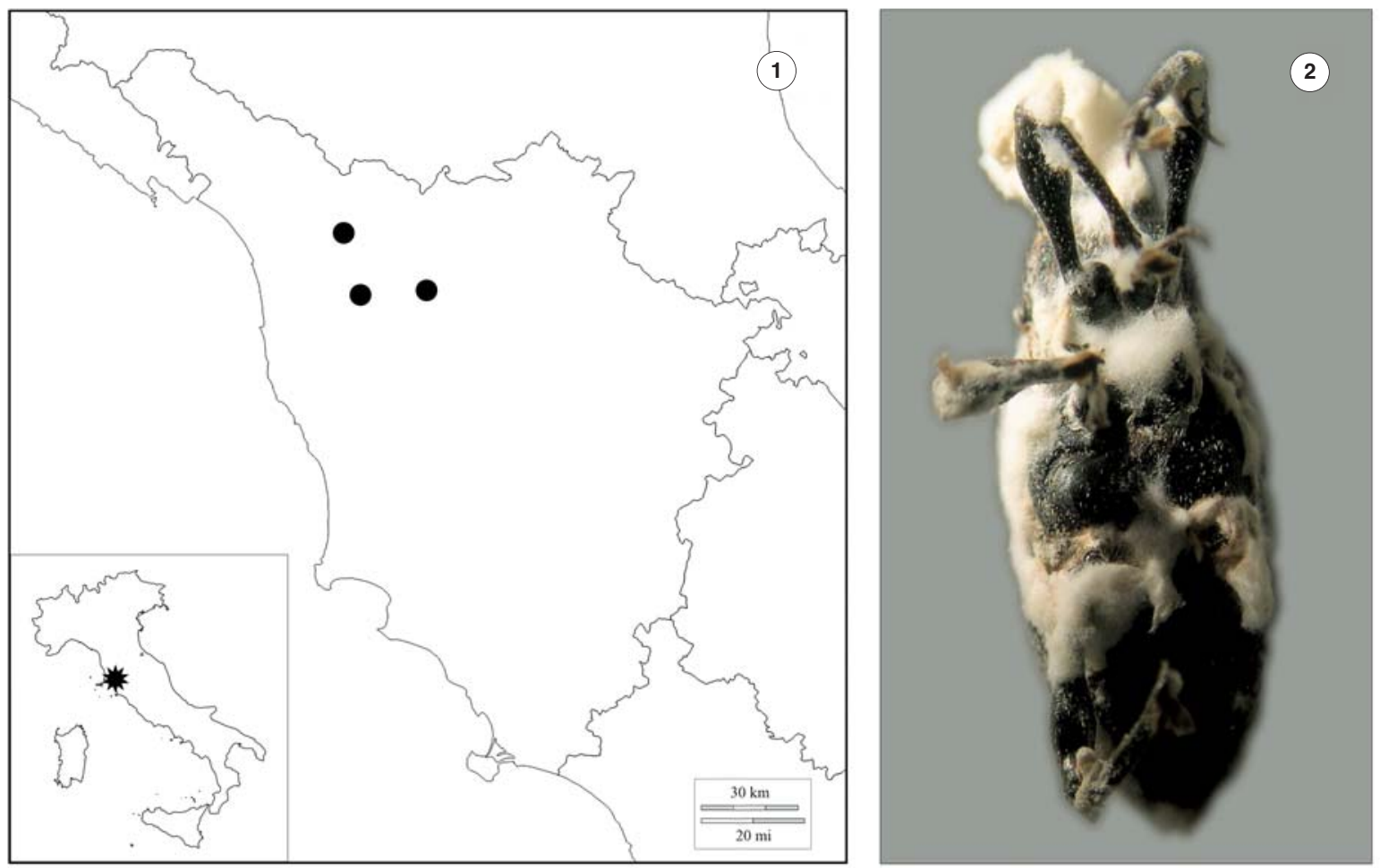

Fig. I - (1) Sites of collection of Aclees sp. cf. foveatus in Tuscany (Italy). (2) Dead specimen of Aclees sp. cf. foveatus found in Carmignano (Prato) and infected by Beauveria bassiana strain Bb 15/I13.

accomplished using formulated insecticide products; in particular the biological agents are all commercial products in Italy, with the exception of one of the nematodes, belonging to a laboratory collection.

\section{Pathogenicity assays with entomopathogenic nematodes}

Capsanem ${ }^{\circledR}$ containing Steinernema carpocapsae (Weiser) nematodes (Koppert B.V., The Netherlands), and Heterorhabditis bacteriophora Poinar ItH-LU1 (collection of the Section of Entomology and Zoology - DISSPA, University of Bari) were used in this study. In particular, $H$. bacteriophora was reared at $24{ }^{\circ} \mathrm{C}$ on the greater wax moth Galleria mellonella L. larvae and the Infective Juveniles that emerged from cadavers were recovered using modified White traps (KAYA \& STOCK, 1997). After storage at $12{ }^{\circ} \mathrm{C}$ for 2 weeks, they were kept at $20^{\circ} \mathrm{C}$ for $24 \mathrm{~h}$ prior to testing.

Experimental unit ( $\mathrm{n}=15$ for each of the two treatments) consisted in a plastic cup (4.5 $\mathrm{cm}$ diameter, $7 \mathrm{~cm}$ deep) filled with $60 \mathrm{cc}$ of sterile peat and water (1:1). A dose of $50 \mathrm{IJs} / \mathrm{cm}^{2}$ (800 nematodes/insect) was applied onto the soil surface of each cup in $0.5 \mathrm{ml}$ of water. In the control cup $(n=15)$, we added only sterile water. An adult was inserted in each cup and fed ad libitum with apple. Cups were closed with perforated plugs and then, they were incubated at $24 \pm 2{ }^{\circ} \mathrm{C}, 60-80 \% \mathrm{RH}$, under a natural light:dark (L:D) cycle regime (about 11:13) for 28 days. Insect mortality was checked daily.

\section{Pathogenicity assays with entomopathogenic fungi}

Metarhizium anisopliae var. anisopliae (Metschnikoff) Sorokin strain F52 (Met52 ${ }^{\circledR}$, Novozymes A/S - 9 x $10^{8}$ $\mathrm{CFU} / \mathrm{g}$ ) and B. bassiana strain ATCC74040 (Naturalis ${ }^{\circledR}$, Biogard $/ \mathrm{CBC}-2.3 \times 10^{7}$ conidia $/ \mathrm{ml}$ ) were used in the present study.

Experimental unit ( $\mathrm{n}=15$ for each treatment) consisted in the same plastic cup described above. For both fungi $\left(\right.$ Met52 $^{\circledR}$ and Naturalis ${ }^{\circledR}$ ) the label dose was applied onto the soil surface of each cup. In the control cup $(n=15)$, only sterile water was added. A single adult was inserted in each cup and the setting of the experimental units was made as for the test described above.

An additional biossay was performed with Naturalis ${ }^{\circledR}$, treating single adults $(n=15)$ by direct application of $1 \mu \mathrm{L}$ suspension of the product. The adults were kept in the same experimental units used above. Control adults $(n=15)$ received only $1 \mu \mathrm{L}$ of distilled water.

Insect mortality was checked daily. Dead weevils were surface sterilized with $1 \%$ sodium hypochlorite, rinsed three times with sterile distilled water, and placed on moistened filter paper in Petri dishes at $25 \pm 1{ }^{\circ} \mathrm{C}$ to determine the presence of external sporulation according to CiTo et al. (2014).

\section{Data ANALYSIS}

Lethal time to $50 \%\left(\mathrm{LT}_{50}\right)$ was estimated. Data from the pathogenicity bioassays were compared using Wilcoxon Gehan test (statistic: $\chi^{2}$ ). All tests were performed with SPSS v. 15.0 software.

\section{RESULTS}

\section{ISOLATION AND IDENTIFICATION OF THE FUNGAL STRAIN}

On the basis of morphological and molecular data, the fungal strain found in association with the dead weevil was identified as Beauveria bassiana. Consensus tree obtained by ML and BI algorithm support this identification (Fig. II), however some differences could be found between the tree reconstructions, in particular BI algorithm distinguish Beauveria lii and Beauveria varroae from $B$. bassiana while ML bootstrap does not. A possible explanation for the low ML resolution could be the 


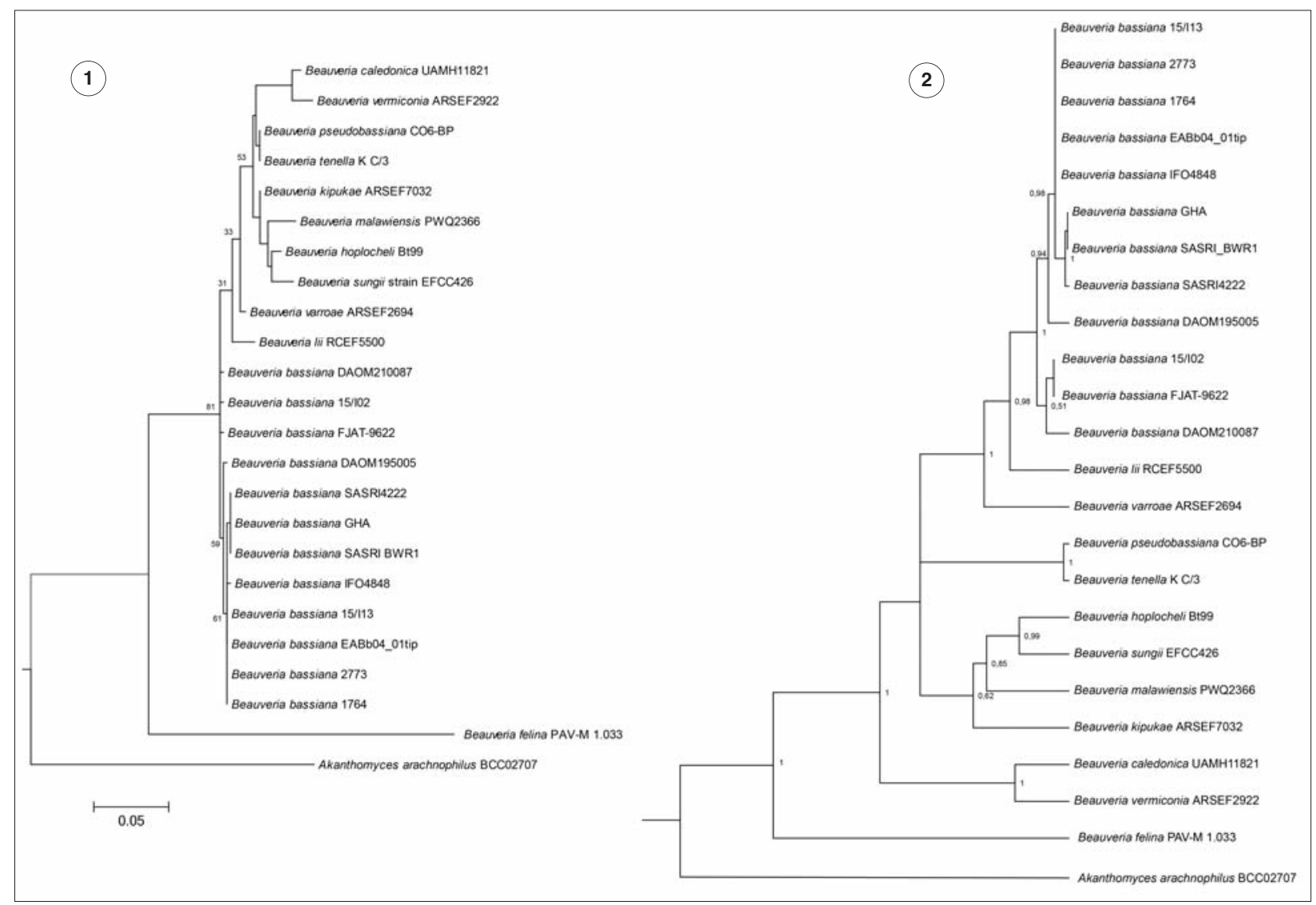

Fig. II - Species identification of fungal isolate based on two phylogenetic reconstructions using Maximum Likelyhood (ML) and Bayesian Inference (BI) methods. (1) ML tree include isolate 15/I13 in Beauveria bassiana clade $(-\operatorname{lnL}=-$ 1537.1707); bootstrap values are reported near respective nodes. (2) BI tree identify isolate $15 / \mathrm{I} 13$ as B. bassiana $(-\operatorname{lnL}=$ -1779.38); each node was annotated with its posterior probability.

closeness of these species (in particular $B$. lii) from $B$. bassiana (ZHANG et al., 2013).

The strain (labeled as $\mathrm{Bb} 15 / \mathrm{I} 13$ ) was isolated and stored into the Ult-Freezer-Haier at $-80^{\circ} \mathrm{C}$ as frozen dried cultures at the entomopathogenic micro-organisms collection of the CREA-ABP of Florence.

\section{PATHOGENICITY ASSAYS}

No mortality was observed using entomopathogenic nematodes, nor by using the commercial product Capsanem ${ }^{\circledR}$ neither with the lab strain ItH-LU1 and, likewise, no effect was obtained by the treatments with the commercial product Met52 ${ }^{\circledR}$, based on M. anisopliae.

On the contrary, noteworthy are the results obtained with both the bioassays using $B$. bassiana Naturalis ${ }^{\circledR}$. The percentage of mortality for both treatments was $100 \%$ and $90 \%$ and the percentage of sporulation was $90 \%$ and $80 \%$, respectively. In particular, the $\mathrm{LT}_{50}$ for the first assay is 8.5 days and for the second one is 7 days. There was no difference in the mortality caused by the two different treatments $\left(\chi^{2}=0.38\right.$, d.f. $\left.=1, P=0.538\right)$, while significant differences were found between both treatments and the control $\left(\chi^{2}=13.91\right.$, d.f. $=1, \mathrm{P}<0.0001 ; \chi^{2}=11.76$, d.f. $=$ $1, \mathrm{P}<0.001$, respectively; Fig. III).

\section{DISCUSSION}

This is the first finding of an entomopathogenic fungus associated to Aclees sp.cf. foveatus. This record agrees with the promising results obtained from the pathogenicity assays with Beauveria bassiana performed in lab condition. As highlighted also for another invasive weevil, Rhynchophorus ferrugineus (Olivier) (MAzza et al., 2014b) and as indicated in the results, Aclees showed a different susceptibility towards different entomopathogenic fungi, while no effect was obtained using our entomopathogenic nematodes. The use of $B$. bassiana, moreover found as the only natural enemy in our environments, should be seriously considered for biological control and for inclusion in integrated pest management programs. Further studies are necessary to better understand the species behaviour in order to address management techniques with special reference to the temporal placement of the treatments against adults. In the case of Aclees, most of the life cycle is completed within the fig trunk, making the preimaginal stages inaccessible to direct-contact treatment, thus the adults are the only exposed stage that can be infected upon the emergence. Moreover it is important to continue the research of new biocontrol agents for an environmental friendly approach.

\section{ACKNOWLEDGMENTS}

We would like to thank E. Tarasco (DISSPA) to provide Heterorhabditis bacteriophora strain, G.P. Barzanti (CREA-ABP) for the help in the isolation and identification of the fungal strain. Thanks to Siro Petracchi (Associazione produttori fichi secchi di Carmignano), Ivo 


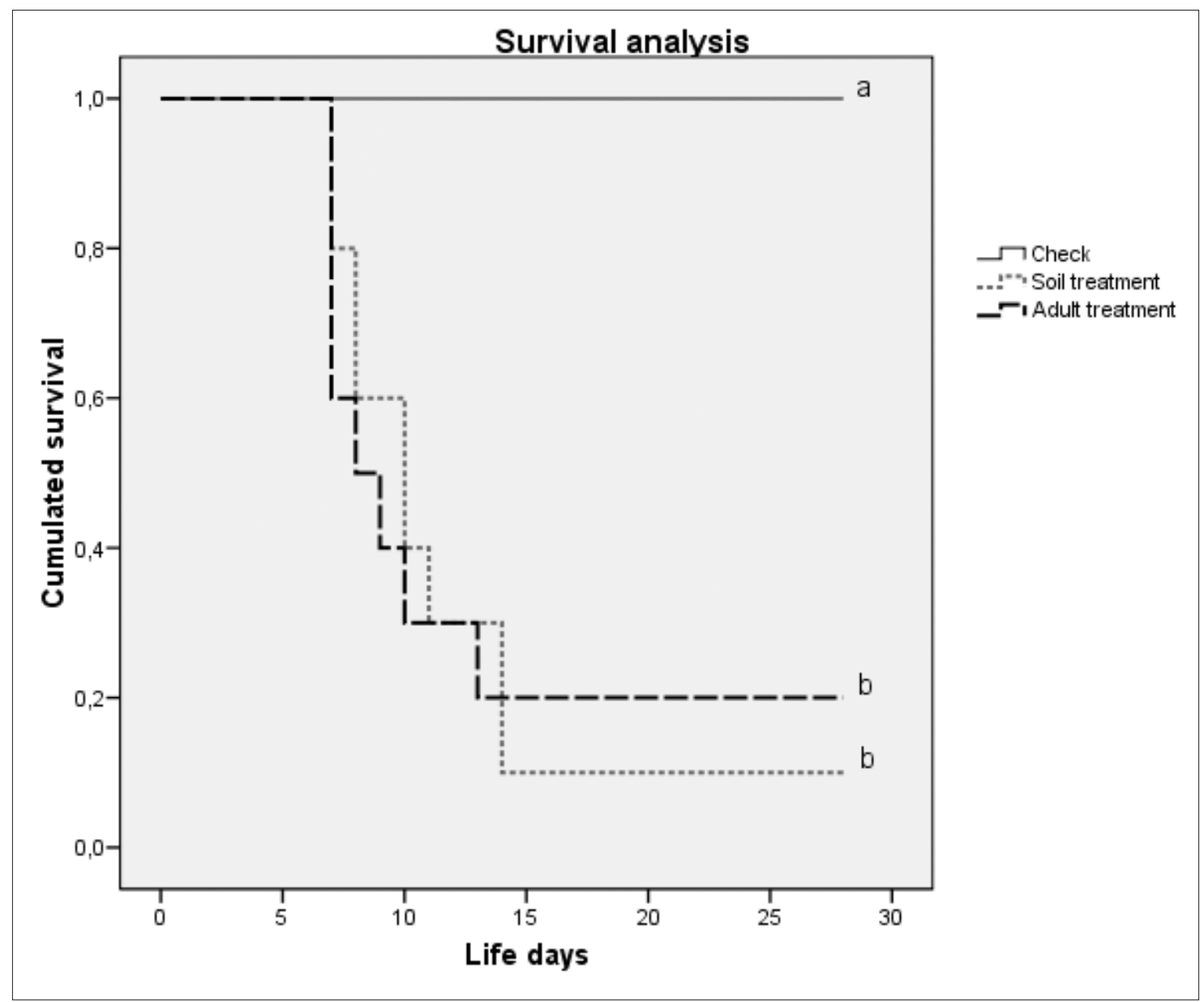

Fig. III - Survival analysis of Aclees sp. cf. foveatus adults treated with Naturalis ${ }^{\circledR}$. Lines with the same letter are not significantly different.

Poli and Claudio Lorenzi (fig nurseries owners). Thanks to Nancy Ricceri for the english revision.

\section{RIASSUNTO}

\section{PROVE DI CONTROLLO BIOLOGICO DI ACLEES SP. CF. FOVEATUS E PRIMO RITROVAMENTO IN NATURA DI UN CEPPO DI BEAUVERIA BASSIANA ASSOCIATO AD ESSO}

Aclees sp. cf. foveatus (Coleoptera: Curculionidae) si sta rapidamente diffondendo in Italia centrale, causando gravi infestazioni su alberi di fico. Pochissime sono le informazioni su questo fitofago e non risultano segnalati nemici naturali. In questo articolo, si riporta il primo ritrovamento di un nemico naturale associato a questo curculionide invasivo, un ceppo del fungo entomopatogeno Beauveria bassiana. Prove di patogenicità, su adulti, sono state effettuate in laboratorio per valutare la potenziale efficacia di funghi entomopatogeni e nematodi come agenti di biocontrollo. In sintonia con il ritrovamento in natura, solo i trattamenti con B. bassiana sono stati in grado di controllare gli insetti. Questo risultato apre nuove frontiere per strategie di controllo del curculionide con prodotti ad elevata sostenibilità ambientale.

\section{REFERENCES}

Benelli G., Meregalli M., Canale A., 2014 - Field observations on the mating behavior of Aclees sp. $c f$. foveatus Voss (Coleoptera: Curculionidae), an exotic pest noxious to fig orchards. - Journal of Insect Behavior, 27: 419-427.

Ciampolini M., Perrin H., Regalin R., 2005 - Aclees cribratus, nuovo per l'Italia nocivo al fico allevato in vivaio. - Informatore Agrario, 61: 69-71.

Ciampolini M., Regalin R., FARnesi I., Lorenzi C., 2007 - Prime osservazioni sulla bio-etologia di Aclees sp.(Curculionidae, Molytinae) esiziale a Ficus carica $L$. in Italia. - Bollettino di Zoologia Agraria e di Bachicoltura, 39: 51-60.

Ciampolini M., Farnesi I., Scarselli F., Lorenzi C., 2008 - Contro il curculionide del fico decisiva la lotta agli adulti. - Informatore Agrario, 64: 57.

Cito A., Mazza G., Strangi A., Benvenuti C., Barzanti G.P., Dreassi E., Turchetti T., Francardi V., Roversi P.F., 2014 - Characterization and comparison of Metarhizium strains isolated from Rhynchophorus ferrugineus. - FEMS Microbiology Letters, 355: 108-115.

DRUMMOND A., RAMBAUT A., 2007 - BEAST: Bayesian evolutionary analysis by sampling trees. BMC Evol Biol 7: 214 . 
Glass N.L., Donaldson G.C., 1995 - Development of primer sets designed for use with the PCR to amplify conserved genes from filamentous Ascomycetes. Applied and Environmental Microbiology, 61: 13231330.

Kaya H.K., Stock S.P., 1997 - Techniques in Insect Nematology, In: L.A. Lacey Ed, Manual of Techniques of Insect Pathogens Academic Press, London, UK. pp. 281-324.

Mazza G., Chouaia B., Lozzia G.C., Montagna M., 2014a - The bacterial community associated to an Italian population of Psacothea hilaris: a preliminary study. Bulletin of Insectology, 67: 281-285.

Mazza G., Francardi V., Simoni S., Benvenuti C., Cervo R., Faleiro J.R., Llacer E., Longo S., Nannelli R., TARASCO E., RoverSI P.F., 2014b - An overview on the natural enemies of Rhynchophorus palm weevils, with focus on R. ferrugineus. - Biological Control, 77: 83-92.

Mогімото K., 1982 - The family curculionidae of Japan. I. Subfamily Hylobiinae. - Esakia: 51-121.
Pollini A., 1998 - Manuale di Entomologia Applicata. Edagricole, Bologna, Italy.

Tamura K., Stecher G., Peterson D., Filipski A., Kumar S., 2013 _ Mega6: Molecular evolutionary genetics analysis version 6.0. - Molecular Biology and Evolution, 30: 2725-2729.

Thu P.Q., Quang D.N., Dell B., 2010 - Threat to cedar, Cedrela odorata, plantations in Vietnam by the weevil, Aclees sp. - Journal of Insect Science, 10: 192. available online: insectscience.org/10.192.

White T.J., Bruns T., Lee S., Taylor J., 1990 Amplification and direct sequencing of fungal ribosomal RNA genes for phylogenetics. In: M. Innis, D. Gelfand, J. Sninsky, T.J. White Eds., Pcr protocols: A guide to methods and applications . - Academic Press, New York, USA. pp. 315-322.

Zhang S.L., He L.M., Chen X., Huang B., 2013 Beauveria lii sp. nov. isolated from Henosepilachna vigintioctopunctata. - Mycotaxon, 121: 199-206. 
